\title{
DUAL ROLE OF CATHEPSIN D: LIGAND AND PROTEASE
}

\author{
Martin Fusek ${ }^{\mathrm{a}}$, Václav Větvička ${ }^{\mathrm{b} *}$
}

\author{
a Institute of Organic Chemistry and Biochemistry, CAS, Prague, Czech Republic, and \\ b University of Louisville, Department of Pathology, Louisville, KY40292, USA, \\ e-mail:vaclav.vetvicka@louisville.edu
}

Received: April 15, 2005; Accepted (with revisions): June 20, 2005

Key words: Cathepsin D/Procathepsin D/Cancer/Activation peptide/Mitogenic activity/Proliferation

Cathepsin D is peptidase belonging to the family of aspartic peptidases. Its mostly described function is intracellular catabolism in lysosomal compartments, other physiological effect include hormone and antigen processing. For almost two decades, there have been an increasing number of data describing additional roles imparted by cathepsin $\mathrm{D}$ and its pro-enzyme, resulting in cathepsin D being a specific biomarker of some diseases. These roles in pathological conditions, namely elevated levels in certain tumor tissues, seem to be connected to another, yet not fully understood functionality. However, despite numerous studies, the mechanisms of cathepsin D and its precursor's actions are still not completely understood. From results discussed in this article it might be concluded that cathepsin D in its zymogen status has additional function, which is rather dependent on a "ligand-like" function then on proteolytic activity.

\section{CATHEPSIN D - MEMBER OF ASPARTIC PEPTIDASES FAMILY}

Major function of cathepsin D is the digestion of proteins and peptides within the acidic compartment of lysosome ${ }^{1}$. This function is allowed by the catalytic mechanism given by two aspartate residues in the deep cleft of the active side. The common catalytic mechanism, together with low optimal $\mathrm{pH}$ for their catalytic function and high level of similarity of both primary and tertiary structures, are the reasons why cathepsin D belongs to the aspartic peptidase A1 family ${ }^{2}$. The A1 family of aspartic peptidases includes most of aspartic endopeptidases found in human organism. Gastric juice contains pepsin A (ref., ${ }^{3,4}$ ) and gastricsin ${ }^{5}$, while rennin is found in kidney and blood $^{6}$. Limited distribution within human organism has also cathepsin E, an intracellular non-lysosomal aspartic peptidase ${ }^{7}$. Expression limited to brain tissues has memapsin ( $\beta$-secretase), which seems to be one of the crucial enzymes involved in the development of Alzheimer disease $^{8}$. Cathepsin D, on the contrary, is found in lysosomes of most of human cells ${ }^{9}$. The fundamental function of all members of family A1 of aspartic peptidases is to catalyse the hydrolysis of peptidic bond/s in peptides or proteins. Pepsin is a key enzyme in the digestive system and cleaves food proteins in the acidic milieu of the stomach with broad specificity. Rennin, on the other hand, having very restricted specificity and optimum conditions at higher $\mathrm{pH}$, hydrolyses only angiotesinogen and therefore acts to control blood pressure ${ }^{10}$. Cathepsin D effects intracellular digestion within the lysosomal compartments.

\section{PRIMARY, SECONDARY AND TERTIARY STRUCTURES OF ASPARTIC PEPTIDASES}

There is a high degree of sequence similarity among eukaryotic members of the family of aspartic peptidases, e.g., triades Asp-Thr-Gly around the two active site aspartic residues (number 32 and 215, numbering of the human pepsin A) are virtually identical. But the similarity of primary structures goes beyond these short motifs. Much the same, but not identical, are sequences of the activation peptides. Long segments around the aspartic triades are highly conserved. The position of cystein residues and of tyrosin 75 and its surroundings is also conserved. Tyrosin 75 is localized in a so-called flap region, which is flexible and partially covers the active side. Notably, there is internal sequence similarity as well. This internal symmetry in primary structures is observed on the level of primary, secondary and tertiary structures. Peptidases belonging to the A1 family are formed by bi-lobal structure and both lobes are structurally similar which suggests a common ancestor - a dimeric molecule consisting of two identical subunits - which by gene duplication and gene fusion evolved into monomeric bilobal structure ${ }^{11}$.

In terms of secondary structure, most of the motifs are $\beta$-structures with short segments of $\alpha$-helices. The tertiary structure is for most human aspartic peptidases well described: pepsinogen A and pepsin ${ }^{12,13,14,15}$ for cathepsin $\mathrm{D}\left(\right.$ ref. $^{16,17}$ ) and for rennin ${ }^{18,19}$ and memapsin ${ }^{8}$. The overall shapes as well as many details of these structures are very similar. All of these peptidases contain a deep active cleft, which is formed by walls of the two lobes. Located at the bottom of this cleft are two active aspartic acid residues. 
As shown by the 3D X-ray analysis using co-crystallization with tightly binding inhibitors, the active site cleft forms the binding milieu for attachment of either the inhibitor or substrate.

In the aspartic peptidases there are typically three disulfides positioned in very conservative places. Cathepsin $\mathrm{D}$ has, in addition, one disulfide formed between cystein residues 27 and 96 .

\section{POSTTRANSLATIONAL PROCESSING}

Glycosylation occurs only in cathepsin D, cathepsin E. and memapsin. Other members of human aspartic peptidases have not been reported to contain sugar moiety.

Another important feature of aspartic peptidases is the structural changes accompanying the transformation of newly translated proteins into zymogens and subsequently into active enzymes. All human aspartic peptidases are synthesized as pre-pro-enzymes. In the first proteolytic posttranslational modification, the signal "pre" sequence is cleaved off. This signal sequence is usually 20 amino acids long and is removed within the rough endoplasmatic reticulum. Zymogens, formed by this first posttranslational processing, then travel to a place of their action and only when they reach the particular compartment or tissue are they activated into the fully active enzymes. The activation involves cleavage off of the pro-sequence, which is also called the propeptide or the activation peptide. A schematic representation of the general features of sequences of aspartic peptidases and specific features of cathepsin D are shown in Fig. 1.

The activation peptide is usually 40-60 amino acids long. The activation can proceed by both intramolecular and intermolecular mechanisms. E.g., human pepsinogen A can be converted into fully mature enzyme without help of other molecules ${ }^{20}$, while cathepsin D needs catalysis of other lysosomal peptidases to reach full maturation ${ }^{21}$.

A detailed study of this behavior in the case of cathepsin D revealed that cathepsin D during autoactivation forms only so called pseudo-cathepsin D, still containing the $\mathrm{C}$-terminal part of the activation peptide attached to the sequence of the mature enzyme. The full activation can be achieved only with the help of other lysosomal peptidases.

\section{THE ACTIVE SITE AND SUBSTRATE SPECIFICITY, PEPSTATINE A}

Aspartic peptidases can accommodate up to 9 amino acids long substrate into their active site binding cleft. Using annotation as described by Schechter ${ }^{22}$, the binding sites are from $\mathrm{S}_{5}$ up to $\mathrm{S}_{3}$, around the scissile bond. As mentioned above, the specificity differs among the different peptidases. Pepsin has very broad specificity while rennin has very restricted specificity. Cathepsin D is similar to both having lower specificity than rennin but requires more specific substrates then pepsin. Similar to pepsin, cathepsin D prefers two hydrophobic residues around the hydrolysed bond.

An important feature common to many aspartic peptidases is their inhibition by pepstatine A. Pepstatine A is noncovalent, competitive, tight-binding inhibitor isolated from culture filtrates of various Streptomyces ${ }^{23}$. Pepstatine A forms multiple, noncovalent bonds with the active site residues of the aspartic peptidases and the inhibition constant is in nanomolar range for pepsin, cathepsin D and other aspartic peptidases ${ }^{24}$.

\section{CATHEPSIN D A LYSOSOMAL PEPTIDASE - THE TARGETING SIGNAL AND MATURATION}

\section{Intracellular transport of procathepsin $D$}

An important feature of cathepsin D's normal cellular life is its rather strict localization within acidic compartments of lysosomes and different pre-lysosomal and endosomal vesicles. There are at least two ways by which cells target cathepsin D into these compartments. First, the presence of mannose-6-phosphate (M6P) tag at the terminus of the oligosaccharides attached during post-translational modification is recognized by two receptors that, similar to other lysosomal enzymes, transport procathe-

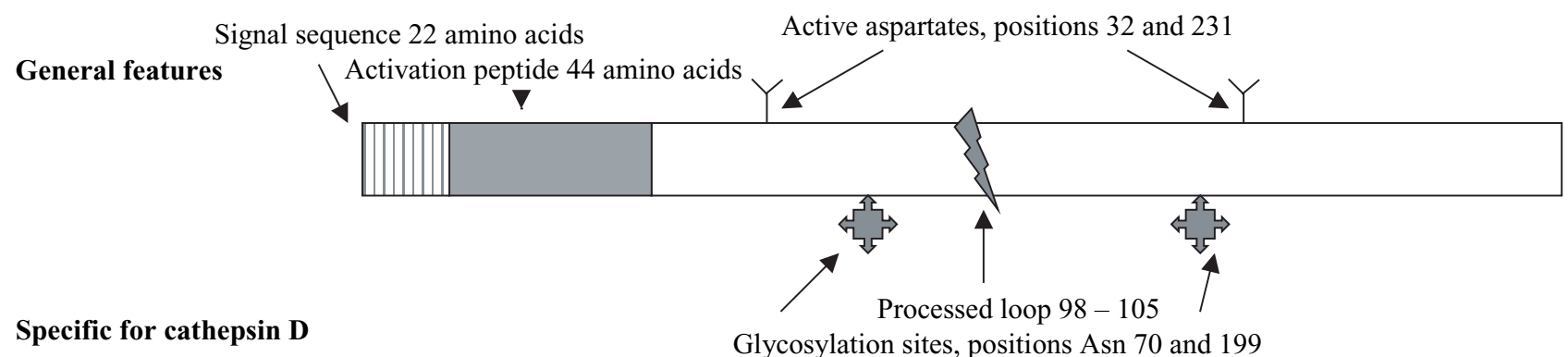

Fig. 1. Schematic representation of structure of aspartic peptidases. If a dashed part of the sequence is compared we will find high level of similarity between the two parts both in primary, secondary and tertiary structures. Cathepsin D is processed into two chain enzyme in around the position 95 as pointed out on the figure. 
psin D to lysosomes and other acidic compartments ${ }^{25,26}$. The two M6P receptors (M6Pr) are cation-independent M6Pr which has molecular weight close to $300 \mathrm{kDa}$ and cation-dependent M6Pr with molecular weight of $46 \mathrm{kDa}$. Both receptors capture lysosomal enzymes in the transGolgi network, form complexes and are then translocated via clathrin coated vesicles to the prelysosomal acidic compartments. Low $\mathrm{pH}$ releases lysosomal enzymes from the receptors and the receptors recycle back to Golgi compartments while lysosomal enzymes continue towards the lysosomes. Both M6Pr are also present on the surface of the plasma membrane and the cation-independent $\mathrm{M} 6 \mathrm{Pr}$ also prevents cathepsin D or procathepsin D from escaping the cellular environment and is able to bind extracellular procathepsin D and internalize it. In reality, function of this $\mathrm{M} 6 \mathrm{Pr}$ is more complicated. The cation-independent M6Pr, in addition to binding and targeting lysosomal enzymes, also functions as a receptor for insulin-like growth factor II.

The second way to target procathepsin D to lysosomes is independent of the M6P tag and, despite extensive research, is not yet fully understood ${ }^{27,28}$. Results of Hasilik's group suggest that certain role in this M6Pr-independent targeting of lysosomal enzymes (namely studies were done with procathepsin D) is played by the interaction of procathepsin $\mathrm{D}$ with prosaponins. These two molecules form complexes and travel together to acidic compartments, independently of M6Pr. It was suggested that the
$\mathrm{N}$-terminal part of pseudoCathepsin D (in other words the $\mathrm{C}$-terminus of the activation peptide) may be involved in this interaction between procathepsin D prosaponin. It was also shown that complexes of these two molecules are found extracellularly ${ }^{29}$. The entire process that supposedly occurs in normal cells is schematically represented in Fig. 3.

\section{Processing of procathepsin $D$}

Similar to other aspartic peptidases, mature cathep$\sin \mathrm{D}$ is formed after several proteolytic changes occurring in different cellular compartments. Procathepsin D originates after the first proteolytic cleavage involving the removal of the signal peptide by signal peptidases. The molecule of procathepsin D has a molecular weight of 52 $\mathrm{kDa}$. It consists of 392 amino acids and is, under normal conditions, glycosylated at two Asn residues. The activation peptide is a 44 amino acid long peptide which is folded in and above the active site cleft as suggested from analogy to pepsinogen molecule and from modeling of the procathepsin D molecule ${ }^{30}$.

Procathepsin D is transported to lysosomes and in the acidic milieu undergoes further proteolytic processing wherein the activation peptide is cleaved off (by both autoproteolysis and proteolytic action of other, mainly cysteine lysosomal peptidases) forming cathepsin D consisting of one chain of 348 amino acids (apparent mol. weight $44 \mathrm{kDa}$ ). Under physiological conditions, human,

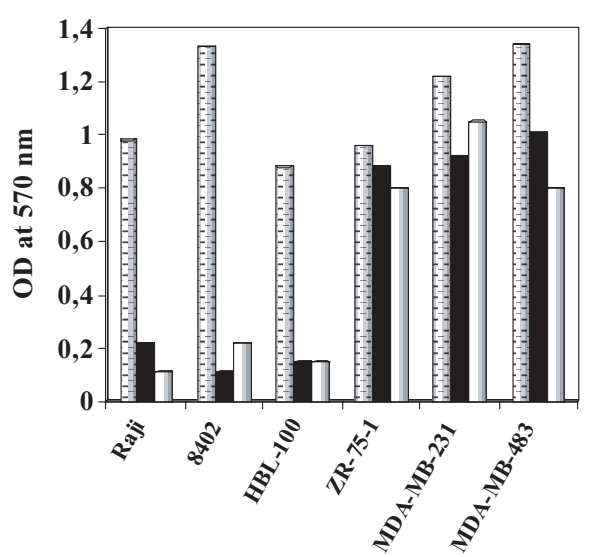

Fig. 2. Results of typical experiments on mitogenic activity of procathepsin D. Growth of various human cell lines in serum-free medium containing either $5 \%$ FCS (+ FCS), $40 \mathrm{ng} / \mathrm{ml}$ procathepsin D (pCD) or $50 \mathrm{ng} / \mathrm{ml}$ activation peptide (APpCD). $5 \times 10^{4}$ cells $/ \mathrm{ml}$ was cultivated in the $96-$ well plates in Iscove's modified Dulbecco's medium with HEPES and transferrin in the presence or absence of additives described above. After 5 days in culture, the proliferation was evaluated using an MTT assay.

\section{Intracellular space}

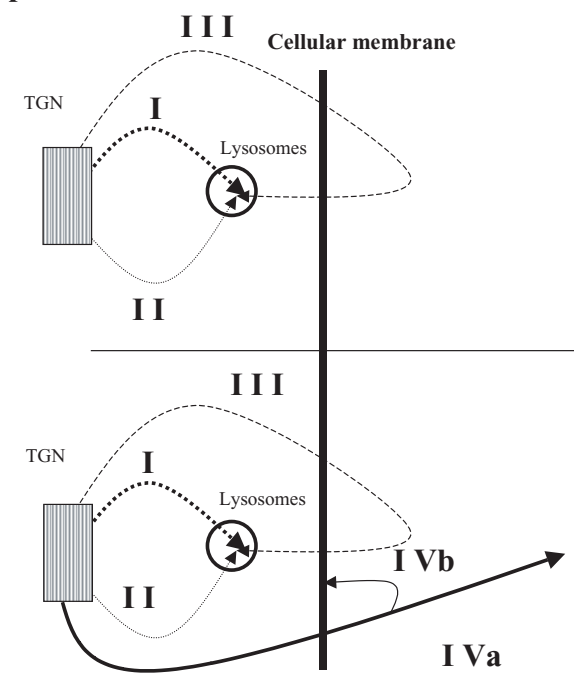

Cancer cell

Fig. 3. Targeting of procathepsin D in normal and cancer cells. In normal cells procathepsin D is targeted with the help of M6Pr to acidic prelysosomal compartments, subsequently it is moved to lysosomes (route I). The route II is independent of M6Pr. Part of procathepsin D can escape but is endocytosed with the help of M6Pr (route III). In the case of cancer cells certain amount of pCD is secreted from the cell and can function as an autocrine mitogen (route IVb) or as a paracrine mitogen (route IVa). 
pig and cattle transform single chain of cathepsin $\mathrm{D}$ into a two-chain molecule (in humans by cleaving off a small peptide of 7 amino acids between positions 98 through 105). Typically, an isolate of cathepsin D from human tissue would consist of three bands: a minor one of apparent molecular weight of $44 \mathrm{kDa}$ and two shorter ones - $31 \mathrm{kDa}$ and $14 \mathrm{kDa}\left(\right.$ ref. $\left.^{31}\right)$. In reality, the heavy and light chains are usually represented by a mixture of several microheterogeneous bands that differ due to minute changes in their molecular weight. In vitro experiments showed that autoproteolysis of procathepsin D leads to so-called pseudoCathepsin. PseudoCathepsin D still contains the C-terminal part of the activation peptide.

\section{Cathepsin D - physiological functions}

It is widely accepted that the major function of cathepsin D is the intracellular catabolism within the lysosomal compartment (1). Cathepsin D is apparently also involved in the processing of antigens ${ }^{32}$, hormones, and neuropeptides. Of interest, a relatively high concentration of procathepsin $\mathrm{D}$ was found in human breast milk ${ }^{33}$ suggesting as yet unknown function. Tissue remodeling represents another involvement of cathepsin D in mammal physiology ${ }^{34}$. Procathepsin D was also suggested to take part in programmed cell death - apoptosis ${ }^{35,36,37,38}$.

While majority of cathepsin D is found in soluble parts of most of human cells, about $20 \%$ is apparently membrane bounded ${ }^{39,40}$.

\section{Cathepsin D involvement in cancer}

When studying major proteins secreted by breast cancer cell line MCF7 in early eighties, the Rochfort's group found that the most abundant protein is a molecule of molecular weight $52 \mathrm{kDa}\left(\right.$ ref. $\left.^{41}\right)$. Further studies revealed that this molecule corresponds to procathepsin $\mathrm{D}$, which is secreted at high level from certain types of breast cancer tumors in a presence of estrogen. Twenty-five years later, it is very well documented that procathepsin $\mathrm{D}$ is overexpressed and secreted in many cancer-derived cell lines and in many of them the addition of estrogen and progesterone are increasing the expression and secretion ${ }^{42,43}$. In estrogen receptor positive $\left(\mathrm{ER}^{+}\right)$cell lines, procathepsin $\mathrm{D}$ is secreted only after estrogen stimulation, while it is secreted constitutively in $\mathrm{ER}^{-}$cell lines. In $\mathrm{ER}^{+}$cell lines, estrogen interacts and regulates the expression of procathepsin $\mathrm{D}$ at promoter leve ${ }^{44}$. These findings have led to one branch of research that can be designated "prognostic value of cathepsin D in cancer." However, in addition to measurable, abnormal secretion of procathepsin $\mathrm{D} /$ cathepsin $\mathrm{D}$ from certain tumor cells and tissues, several groups have found that secreted procathepsin D has the ability to stimulate growth and cancer cell proliferation ${ }^{45,46}$. Based on reports of both Rochefort's group and our own team, we propose that secreted procathepsin D both helps the cancer cells to proliferate and to form metastases.

\section{PROGNOSTIC VALUE - BREAST CANCER, ENDOMETRIAL CANCER}

It was shown that cathepsin D can serve as an independent prognostic factor in many types of cancers. A strong predictive value was found for cathepsin D concentrations in breast cancer as well as many other tumor types ${ }^{47,48,49,50}$. Using the monoclonal antibodies specific for the pro-form, it has been shown that the procathepsin $\mathrm{D}$ level increases in plasma of patients with metastatic breast carcinoma ${ }^{51}$.

Studies devoted to prognostic value of procathepsin D have shown that, in node-negative breast cancer patients, $\mathrm{CD}$-overexpression was associated with an increased risk of recurrence and death ${ }^{42,52,53}$. These data were not confirmed in male breast cancer ${ }^{54,55}$ and the prognostic value in other gynaecological malignancies is uncertain. But there is a strong relation between levels of procathepsin $\mathrm{D}$ expression and the degree of aggressiveness and chemoresistance of ovarian and endometrial tumors ${ }^{50}$.

\section{OTHER TYPES OF NEOPLASIA}

Procathepsin D presence and function was studied in many types of cancer, in addition to breast cancer tissues. These included tumors of central nervous system, lung cancer, thyroid tumors, gastric cancer, liver cancer, pancreatic cancer, as well as prostatic, bladder, etc. This topic was excellently reviewed by Leto et $\mathrm{a}^{50}$. In general, it can be concluded that procathepsin D is found at elevated levels in both pre-malignant conditions and developed cancers for many types of malignancies. Nevertheless, the prognostic value remains controversial.

\section{INCONSISTENCIES}

Part of the problem in determining the diagnostic value of procathepsin $\mathrm{D}$ is possibly caused by lack of standardized procedures in the determination of its concentration. As indicated below, it is important whether concentration of activated cathepsin D is determined or concentration of procathepsin D is measured or the sum of both is used for the statistical data. It might also be of value to know if total extracellular or intracellular concentrations were measured. Many of studies do not discriminate between procathepsin D and cathepsin D and this is a probable cause of different results obtained by different laboratories. 


\section{MECHANISM OF THE MITOGENIC FUNCTION OF PROCATHEPSIN D IN CANCER}

The increased level and regulation of expression of procathepsin $\mathrm{D}$ in many types of cancer initiated research elucidating the possible mechanisms of the mitogenic, proliferating and other tumor growth-promoting functions of procathepsin D.

Several laboratories have shown that procathepsin D promotes the growth of surrounding cancer cells ${ }^{56,57}$. We have recently undertaken an experiment where the level of procathepsin D translated in cancer cells was down regulated using ribozymes and we compared the proliferation activity of such mutant cells with the non-mutated. We found a strong correlation between the level of procathepsin D translation and the proliferative potential ${ }^{43}$. We have also shown that procathepsin D takes part in the metastatic potential of the cancer cells, which was supported by results evaluating the invasion across the Matrigel membrane. That the invasiveness closely corresponds to the amount of secreted procathepsin $\mathrm{D}$ both in breast ${ }^{43}$ and lung cancer model ${ }^{58,59}$ has also been evidenced.

In principle, one can hypothesize about the following structural/functional features of procathepsin $\mathrm{D}$ being involved in the mitogenic function or functions connected to cancer development in general.

1. proteolytic activity of procathepsin D when exposed to acidic environment

2. presence of the saccharidic moieties (phosphorylated)

3. presence of primary structure interacting with other soluble or insoluble (membrane bounded) molecule

4. different unknown mechanism

In general, these features may include interactions in both extra- and intracellular space. We can look into these possibilities in more detail.

\section{PROTEOLYTIC ACTIVITY}

The proteolytic activity was the first mechanism proposed for the mitogenic and cancer growth functions. However, this remains inconclusive. The over-expression of cathepsin D in cancer cell lines increases the concentration of procathepsin D. This most likely leads to an increased saturation of M6Pr targeting pathway as well as other alternative pathways. It is logical that these cells will also deliver more procathepsin D into lysosomes thus leading to increased proteolytic activity of the lysosomal compartment. On the other hand, cathepsin $\mathrm{D}$ is proteolyticaly active in $\mathrm{pH}$ under 5.5 and it is difficult to find such a low $\mathrm{pH}$ extracellulary in tumor tissues. In principle, the proteolytic activity must remain under consideration. Nevertheless, several experiments support the hypothesis that proteolytic activity is, in this case, not the major reason of increased proliferation of cells incubated with procathepsin D. The study of Fusek and Vetvicka from $1994\left(\right.$ ref. $^{59}$ ) shows that the mitogenic function in vitro was strictly connected to the use of procathepsin D but none was detected when using cathepsin $\mathrm{D}$. The addition of pepstatin A into the experimental mixture did not have any negative influence on the mitogenic activity of procathepsin D.

Very strong argument against the involvement of proteolytic activity has come from experiments when the active site of procathepsin D was mutated (mutation of the active site aspartate 231 into asparagines) and then used for mitogenic experiments both in vitro and in vivo (60). This mutated procathepsin D had retained its mitogenic activity, while proteolytic activity was abolished. Very similar results were obtained by Vetvicka in both in vitro and in vivo conditions for mutants including both active aspartates (data not shown). Laurenth-Matha et al. 2005 have recently shown that catalytically inactive cathepsin $\mathrm{D}$ triggers fibroblast invasive growth ${ }^{61}$. Considering all the gathered evidence, it might be concluded that the proteolytic activity is most likely not involved in described effect and also is not taking part in cancer development.

\section{ROLE OF SUGAR MOIETY}

The role of saccharidic moieties, particularly their possible interaction with mannose-6-phosphate receptors, also gained the attention of investigators. In 1994, we described that the simple removal of the saccharidic chains, using glycosydases, did not have any effect on in vitro mitogenic activities ${ }^{59}$. We also tested the addition of high concentrations of mannose-6-phosphate which might compete in the interaction with receptors and did not detect any loss of the mitogenic activity. Very detailed study of the interaction of procathepsin D with mannose-6-phosphate receptors was done by Rochefort and his team ${ }^{42}$. It was shown that procathepsin D interacts normally in vitro with the M6Pr and can be endocytosed by this receptor. Differences were found in the functionality of this receptor for certain in vivo experiments. It appears that, in certain tumors, the receptor functions abnormally. One hypothesis is that higher concentration of procathepsin $\mathrm{D}$ saturates the cation-independent M6Pr leading to a decrease of binding sites for both M6P tagged proteins and for insulin-like growth factor II. As a consequence, insufficient function of M6Pr can be the cause of alternation of the function of M6Pr and can help the cancerogenesis. Our recent results show that procathepsin D whose glycosylation is abolished by mutation in the glycosylation site does not loose its mitogenic and proliferative activity. This may suggest that neither the M6P tag nor the sugar moiety have any effect on the tumor growth promotion observed for procathepsin D. 


\section{PRIMARY STRUCTURE OF PROCATHEPSIN D MOLECULE IS RESPONSIBLE FOR INTERACTION WITH OTHER MOLECULES AND SUPPORTS THE PROLIFERATION OF PRIMARY CANCER CELLS}

In our early experiments, we observed that the mitogenic function of procathepsin D was abolished using polyclonal antibodies that were raised against synthetic activation peptide of procathepsin D ( ref. $\left.{ }^{62}\right)$. We did not detect any mitogenic activity when using fully activated human cathepsin D. This prompted us to test the synthetic activation peptide for its mitogenic activity. It resulted in the discovery that the activity continues despite having to use higher concentrations of this peptide compared to the concentration of procathepsin D ( ref. $\left.{ }^{57}\right)$. With these combined results, we hypothesize that some of the observed mitogenic functions of procathepsin D are facilitated by the interaction of a peptide sequence within the activation peptide with an unknown receptor. A more detailed study of this feature has enabled us to attribute function to the C-terminal portion of the activation peptide, i.e., to the $\mathrm{N}$-terminal of pseudo cathepsin D (ref. ${ }^{21}$ ). Typical data from an experiment on mitogenic function of procathepsin D are shown in Figure 2. In the light of the recent findings of Hasilik, we are able to construct a hypothesis that procathepsin $\mathrm{D}$ interacts with prosaponins and that subsequent elevated levels of these procathepsin-prosaponin complexes are the cause of mitogenic function.

The importance of the activation peptide for cancerogenesis and metastatic potential is also supported by experiments in vivo. After showing the in vitro effects of both procathepsin $\mathrm{D}$ and activation peptide, we used an animal model in which anti-procathepsin D antibodies reversed breast cancer development. Both anti-procathepsin and anti-activation peptide antibodies have similar effects ${ }^{57}$. Similar to the significant decrease in the size of developing tumors, the survival experiments showed that even 120 days after challenge with tumor cells more than $70 \%$ of treated mice survived. In comparison, all mice in the control group were dead on day $60\left(\right.$ ref. $\left.{ }^{43}\right)$.

Our hypothesis was strengthened even further by the use of complete activation peptide for immunization of athymic mice prior to tumor cell implantation. Whereas the control mice had an average $450 \mathrm{mg}$ tumor at day 56, in the immunized group the average weight was approximately $30 \mathrm{mg}\left(\right.$ ref. $\left.^{43}\right)$.

\section{TWO FACES OF PROCATHEPSIN D CONCLUSION}

Based on the results described above, we conclude that, in all probability, the function of procathepsin $\mathrm{D}$ is not only a precursor of a hydrolytic enzyme within the lysosomes but also includes an interaction with other molecules which has a mitogenic effect in certain tissues. This interaction is most likely facilitated by the activation peptide. This interaction can be part of normal physio- logical function of procathepsin D. However, it becomes dangerous when cancer cells start to over-express and secrete the procathepsin $\mathrm{D}$. This situation is demonstrated in Figure 3. We propose that procathepsin D, which is overexpressed and secreted from primary tumor cells, is affecting growth of both the parental cells and the surrounding cells. This leads to faster growth of the tumor tissue and also increases the risk of metastasis formation. From the experiments described above, it appears that quite a substantial part of this function is undertaken by the sequence within the $\mathrm{C}$-terminal part of activation peptide of procathepsin $\mathrm{D}$.

\section{REFERENCES}

1. Dean RT. (1975) Direct evidence of importance of lysosomes in degradation of intracellular proteins, Nature 257, 414-416.

2. Conner GE. Cathepsin D. In : Barrett AJ, Rawlings ND, Woessner JF editors. Handbook of Proteolytic Enzymes, New York: Academic press 2002. 746-751.

3. Schwann T. (1836) Über das wesen des Verdaungsprocesses. Arch. Anat. Phys. Wiss. Med. 90, 1976,

4. Tang (1970) Gastricsin and pepsin Methods. Enzymol. 19, 406421.

5. Tang J, Wolf S, Caputto R, Trucco R.E. (1959) Isolation and crystallization of gastricsin from human gastric juice. J. Biol. Chem. 234, 1174-1178.

6. Nishimura H. Comparative endocrinology of renin and angiotensin. In: Alan J, Anderson RR, editors. The Renin Angiotensin System. New York, Plenum Publishing, 1980. p. 29-77.

7. Jupp RA, Richards AD, Kay J, Dunn BM, Wyckoff J.B., Samloff IM, Yamamoto K. (1988) Identification of aspartic proteinases from human erythrocyte membranes and gastric mucosa (slow moving proteinase) as catalytically equivalent to cathepsin E. Biochem J. 254, 895-898.

8. Hong L, Koelsch G, Lin XL, Wu SL, Terzyan S, Ghosh AK, Zhang XC, Tang J. (2000) Structure of the protease domain of memapsin 2 ( $\beta$ secretase) complexed with inhibitor. Science 290, 150-153.

9. Fusek M, Vetvicka V. Cathepsin D. In : Fusek M, Vetvicka V. editors. Aspartic Proteinases: Physiology and Pathology. Boca Ratton: CRC Press, 1995. p. 143-184.

10. Hackenthal E, Paul M, Ganten D, Taugner R. (1990) Morphology, physiology, and molecular biology of renin secretion. Physiol.Rev. 70, 1067-1116.

11. Tang J, James MNG, Hsu I, Jenkins JA, Blundell TL. (1978) Structural evidence for gene duplication in the evolution of the acid proteases. Nature 271, 618-621.

12. James MNG, Sielecki AR. (1986) Molecular structure of an aspartic proteinase zymogen, porcine pepsinogen, at $1.8 \AA$ resolution. Nature 319, 33-38

13. Hartsuck JA, Koelsch G, Remington SJ. (1992) The high-resolution crystal structure of porcine pepsinogen. Proteins: Structure, Function, Genetics 13, 1-25.

14. Andreeva NS, Zdanov AS, Gustchina AE, Fedorov AA. (1984) Structure of ethanol inhibited porcine pepsin at $2 \AA$ resolution and binding of the methylester of phenylalanyl-diodotyrosine to the enzyme. J.Biol.Chem. 259, 11353-11365.

15. Cooper JB, Khan G, Taylor G, Tickle IJ, Blundell TL. (1990) X-ray analyses of aspartic proteinases. II Three dimensional structure of the hexagonal crystal form of porcine pepsin at $2.3 \AA$ resolution. J.Mol.Biol. 214, 199-222.

16. Metcalf P, Fusek M. (1993) Two crystal structures for cathepsin D: The lysosomal targeting signal and active site. EMBO J. 12, 1293-1302.

17. Baldwin ET, Bhat TN, Gulnik S, Hosur MV, Sowder RC, Cachau RE, Collins J, Silva AM, Erickson JW. (1993) Crystal structures 
of native and inhibited forms of human cathepsin D: implications for lysosomal targeting and drug design. Proc. Natl. Acad. Sci. USA 90, 6796-6800.

18. Sielecki AR, Hayakawa K, Fujinaga M, Murphy MEP, Fraser M, Muir AK, Carllil CT, Lewicki JA, Baxter JD, James MNG. (1989) Structure of recombinant human rennin, a target for cardiovascularactive drugs, at $2.5 \AA$ A resolution. Science 243, 1346-1351.

19. Rahuel J, Priestle JP, Grutter MG. (1991) The crystal structures of recombinant glycosylated human rennin alone and on complex with transition state analog inhibitor. J.Structural Biol. 107, 227-36.

20. Kageyama T, Ichinose M, Miki K, Athauda SB, Tanji M, Takahashi K. (1989) Difference of activation processes and structure of activation peptides in human pepsinogens A and progastricsin. J.Biochem. 105, 15-22.

21. Conner GE, Richo G. Isolation and characterization of a stable activation intermediate of the lysosomal aspartyl protease cathepsin D. (1992) Biochemistry 31, 1142-1147.

22. Schechter I, Berger A. (1967) On the size of the active site in proteases. I. Papain. Biochem, Biophys, Res. Commun. 27, 157-162.

23. Horishima H, Takita T, Aoyagi T, Takeuchi T, Umezawa H. (1970) The structure of pepstatine, J. Antibiot. 23, 263-271.

24. Abdel-Meguid SS. (1993) Inhibition of aspartyl proteinases. Med. Res.Rev. 13, 731-778.

25. Dahms NM, Lobel P, Kornfeld S. (1989) Mannose-6-phosphate receptors and lysosomal enzyme targeting. J.Biol.Chem. 264, 12115-12118.

26. von Figura K, Hasilik A (1986) Lysosomal enzymes and their receptors. Annu. Rev. Biochem. 55, 167-193.

27. Dittmer F, Ulbrich EJ, Hafner A, Schmahl W, Meister T, Pohlmann R, von Figura K. (1999) Alternative mechanisms for trafficking of lysosomal enzymes in mannose 6-phosphate receptor-deficient mice are cell type-specific. J Cell Sci 112, 1591-1597.

28. Zhu Y, Conner GE. (1994) Intermolecular association of lysosomal protein precursors during biosynthesis. J. Biol. Chem. 269, 3846-3851.

29. Gopalakrishnan MM, Grosch H-W, Locatelli-Hoops S, Werth N, Smolenová E, Nettersheim M, Sandhoff K, Hasilik A. (2004) Purified recombinant human prosaponin forms oligomers that bind procathepsin D and affect its autoactivation, Biochem J. 383 507-15.

30. Koelsch G, Mares M, Metcalf P, Fusek M. (1994) Multiple functions of pro-parts of aspartic proteinase zymogens. FEBS Lett. 343, 6-10.

31. Fusek M, Baudys M, Metcalf P(1992) Purification and crystallization of human cathepsin D. J. Mol. Biol. 226, 555-557.

32. Mohamadzadeh M, Mohamadzadeh H, Brammer M, Sestak K, Luftig RB. (2004) Identification of proteases employed by dendritic cells in the processing of protein purified derivative (PPD). J. Immune Based Ther. Vaccines 2, 8-10.

33. Vetvicka V, Vagner J, Baudys M, Tang J, Foundling SI, Fusek M (1993) Human breast milk contains procathepsin D-detection by specific antibodies. Biochem. Mol. Biol. Int. 30, 921-928.

34. Safting P, Hetman M, Schmahl W. (1995) Mice deficient for the lysosomal proteinase cathepsin D exhibit progressive atrophy of the intestinal mucosa and profound destruction of lymphoid cells. EMBO J. 14, 3599-3608.

35. Bidere N, Lorenzo HK, Carmona S, Laforge M, Harper F, Dumont C, Senik A. (2003) Cathepsin D triggers Bax activation, resulting in selective apoptosis-inducing factor (AIF) relocation in $\mathrm{T}$ lymphocytes entering the early commitment phase to apoptosis. J. Biol. Chem. 278, 31401-31411.

36. Shibata M, Kanamori S, Isahara K, OhsawaY, Konishi A, Kametaka S, Watanabe T, Ebisu S, Ishido K, Kominami E, UchiyamaY. (1998) Participation of cathepsins B and D in apoptosis of PC12 cells following serum deprivation. Biochem. Biophys. Res. Comm. 51, 199-203.

37. Takuma K, Kiriu M, Mori K, Lee E, Enomoto R, Baba A, Matsuda T. (2003) Roles of cathepsins in reperfusion-induced apoptosis in cultured astrocytes. Neurochem. Int., 42 153-9.

38. Deiss LP, Galinka H, Berissi H, Cohen O, Kimchi A. (1996) Cathepsin D protease mediates programmed cell death induced by interferon-gamma, Fas/APO-1 and TNF-alpha. EMBO J., 15, 3861-70.

39. McIntyre GF, Erickson AH. (1991) Procathepsins L and D are membrane-bound in acidic microsomal vesicles. J.Biol.Chem. 266, 15438-15445.

40. Diment S, Leech MS, Stahl PD (1998) Cathepsin D is membraneassociated in macrophage endosomes J.Biol.Chem. 263, 69016907.

41. Rochefort H, Capony F, Garcia M, Cavailles V, Freiss G, Chambon M, Morisset M, Vignon F. (1987) Estrogen-induced lysosomal proteases secreted by breast cancer cells: a role in carcinogenesis? J. Cell. Biochem. 35. 17-29.

42. Rochefort H, Garcia M, Glondu M, Laurent V, Liaudet E, Rey J, Roger P. (2000) Cathepsin D in breast cancer: mechanisms and clinical applications, a 1999 overview. Clin. Chim. Acta. 291, 157-170.

43. Vetvicka V, Benes P, Fusek M. (2002) Procathepsin D in breast cancer: What do we know? Effects of ribozymes and other inhibitors. Cancer Gene Ther. 9, 854-863.

44. Cavailles V, Augereau P, Rochefort H. (1993) Cathepsin D gene is controlled by a mixed promoter, and estrogens stimulate only TATA-dependent transcription in breast cancer cells., Proc. Natl. Acad. Sci. U S A. 90, 203-7.

45. Vignon F, Capony F, Chambon M, Freiss G, Garcia M, Rochefort H. (1986) Autocrine growth stimulation of the MCF 7 breast cancer cells by the estrogen-regulated $52 \mathrm{~K}$ protein. Endocrinology 118 , 1537-1545

46. Vetvicka V, Vetvickova J, Fusek M (1994) Effect of human procathepsin D on proliferation of human cell lines. Cancer Lett. 79, 131-135.

47. Rochefort H. (1992) Biological and clinical significance of cathepsin D in breast cancer. Acta Oncol. 31, 125-130.

48. Rochefort H. (1992) Cathepsin D in breast cancer: A tissue marker associated with metastasis. Eur. J. Cancer 28A, 1780-1783.

49. Leto G, Gebbia N, Rausa L, Tumminello FM. (1992) Cathepsin $\mathrm{D}$ in the malignant progression of neoplastic diseases, Anticancer Res. 12, 235-240.

50. Leto G, Tumminello FM, Crescimanno M, Flandina C, Gebbia N (2004) Cathepsin D expression levels in nongynecological solid tumors: clinical and therapeutic implications. Clin. Exp. Metastases 21, 91-106

51. Brouillet JP, Dufour F, Lemamy G, Garcia M, Schlup N, Grenier J, Mani JC, Rochefort H. (1997) Increased cathepsin D level in the serum of patients with metastatic breast carcinoma detected with a specific pro- cathepsin D immunoassay. Cancer 79, 2132-2136.

52. Ferrandina G, Scambia G, Bardelli F, Panici PB, Mancuso S, Messori A. (1997) Relationship between cathepsin-D content and disease free survival in node-negative breast cancer patients: A meta-analysis. Br. J. Cancer 76, 661-666.

53. Foekens JA, Look MP, Bolt-de Vries J, Meijer-van Gelder ME, van Putten WL, Klijn JG. (1999) Cathepsin-D in primary breast cancer: prognostic evaluation involving 2810 patients. Br. J. Cancer 79, 300-307.

54. Roger S, Day CA, Fox SB. (1993) Expression of cathepsin D and estrogen receptors in male breast carcinoma. Human Pathol. 24, 148-151.

55. Meijer-van Gelder ME, Look MP, Bolt-de Vries J, Peters HA, Klijn JG, Foekens JA. (2001) Clinical relevance of biological factors in male breast cancer. Breast Cancer Res. Treat 68, 249-60.

56. Berchem G, Glondu M, Gleizes M, Brouillet JP, Vignon F, Garcia M, Liaudet-Coopman E. Cathepsin-D affects multiple tumor progression steps in vivo: proliferation, angiogenesis and apoptosis. Oncogene 21,5951-5955.

57. Vetvicka V, Vetvickova J, Hilgert I, Voburka Z, Fusek M. (1997) Analysis of the interaction of procathepsin $\mathrm{D}$ activation peptide with breast cancer cells. Int J Cancer. 73, 403-9.

58. Vetvicka V, Vetvickova J, Benes P. (2004) Role of enzymatically inactive procathepsin D in lung cancer. Anticancer Res. 24, 27392743.

59. Fusek M, Vetvicka V. (1994) Mitogenic function of human procathepsin D-role of the activation peptide. Biochem J 303, 775780. 
60. Glondu M, Coopman P, Laurent-Matha V, Garcia M, Rochefort H Liaudet-Coopman E (2001) A mutated cathepsin D devoid of its catalytic activity stimulates the growth of cancer cells. Oncogene 20, 6920-6929.

61. Laurent-Matha V, Maruani-Herrman S, Prebois C, Beaujoin M, Glondu M, Noel A, Alvarez-Gonzales ML, Blacher S, Coopman
P, Baghdiguian S, Gilles C, Lancarek J, Freiss G, Vignon F, Liaudet-Coopman E. (2005) Catalytically inactive human cathepsin D triggers fibroblast invasive growth. J. Cell Biol. 168, 489-499.

62. Vetvicka V, Vetvickova J, Fusek M. (1999) Anti-human procathepsin D activation peptide antibodies inhibit breast cancer development. Breast. Cancer. Res. Treat. 57, 261-269. 